\title{
Venous Segment
}

National Cancer Institute

\section{Source}

National Cancer Institute. Venous Segment. NCI Thesaurus. Code C132225.

A segment of a blood vessel that is part of the venous system. 